\title{
The Influence of Student-centered Methods in Turkish Language Instruction on Academic Success: A Meta-analysis Study
}

\author{
Nurşat Biçer \\ Department of Turkish Education, Kilis 7 Aralık University, Turkey
}

Copyright $(2017$ by authors, all rights reserved. Authors agree that this article remains permanently open access under the terms of the Creative Commons Attribution License 4.0 International License

\begin{abstract}
The aim of the present study is to determine the influence of student-centered methods employed in Turkish language instruction on the academic success of students through meta-analysis. To this end, a literature review was conducted on the relevant studies conducted between 2000 and 2016 in order to determine the studies were suitable for the meta-analysis. The review revealed that there are 96 studies available on student-centered methods based on multiple intelligences, creative drama, collaboration and games. 22 studies, which qualified for the meta-analysis, were selected and analyses were conducted as necessary. Effect size calculations of the determined methods were made individually. Calculations of the addressed studies were made in accordance with random effects model due to the heterogeneity of effect size calculated in accordance with the fixed effects model. Comprehensive Meta-Analysis CMA software was used for the calculations. This study was deemed necessary due to the unavailability of a study addressed at the methods employed in Turkish language instruction in the literature. As a result of the study, it was determined that student-centered learning methods have an overall positive and high level effect on the academic success of students. The results of the studies combined with meta-analysis suggest that use of student-centered methods in Turkish language instruction is effective on the academic success of students.
\end{abstract}

Keywords Turkish Language Instruction, Meta-analysis, Student-centered Teaching, Academic Success, Effect Size

\section{Introduction}

Instruction of Turkish language is intended for enhancing language skills of students and it is an area which facilitates effectively learning and teaching all lessons rather than merely being a lesson subject. In this sense, Turkish language instruction shapes the academic life of students. Students cannot be expected to succeed in other lessons or everyday life unless they have in-depth knowledge of language and are capable of properly using it in an elaborated manner [55]. Individuals who are competent in their mother tongue and use it in an effective manner are capable of succeeding in all lessons in an easier manner.

The pluralist approach, which has begun to be emphasized in social sciences, has led to language instruction and perspective towards language being addressed together with several social sciences and circumstances. Thus, language has begun to be addressed and examined in a multi-faceted manner, because language is strongly correlated to various branches of science [71]. Interdisciplinary approach model has arisen from emerging theoretical and practical sciences which prepare materials for mother tongue education. In the light of the model, language instruction has gained a strategic dimension and become a subject that needs elaborate thinking. The prominent factors of the human type who catches up with the dynamism of the current age include having the skills of listening, reading, speaking and writing; and knowing the strategies of speed reading; speaking and writing [55]. Individuals who have such skills are capable of succeeding even further in their careers in addition to academic life.

The need for certain rearrangements of Turkish instruction under the influence of new approaches and practices in education has become inevitable. Constructivist approach in Turkish language education and brain-related studies have led to significant changes in the learning areas of approaches and models of language instruction such as reading, writing and understanding [35]. Student-centered education has become prominent upon adoption of constructivist approach in the Turkish Instruction Curriculum developed in 2005 [56]. The prominence of student-centered teaching instead of teacher-centered teaching has led to unidirectional thinking being increasingly replaced by critical thinking as well as by teaching through mental interactions and activities [35]. 
Unlike conventional education, New Turkish Instruction Curriculum has introduced new roles and tasks to teachers. Teacher has become responsible for making the curriculum compatible to students considering their individual characteristics [25]. Teacher seeks to ensure that the process is in favor of the students considering their individual learning characteristics. Having seized the opportunity to learn suitably for themselves, students advance one step further into success.

Upon rapid replacement of conventional behaviorist approach by constructivist approach [33], learning in Turkish language instruction has become based on students constructing and learning information, thus generating new information. This approach has led to prominence of learning rather than teaching [54]. According to the constructivist approach, students:

- Access, interpret and analyze information,

- Improve their mental skills by means of information,

- Integrate prior knowledge into new information, thus reconstructing it [54],

- Assume an active role to obtain knowledge,

- Interpret information by filtering it through experience Özden and Şimşek, 1998, cited in: [33].

The main purpose of constructivist approach is to ensure that students communicate effectively, participate in group study and reconstruct their knowledge in a gradual manner with the guidance of teacher. The role of teacher in this approach involves assisting to and collaborating with students during learning activities. Therefore, student-centered approaches, methods, techniques and instruments are needed in Turkish language instruction [56], because student is positioned at the center of learning environment. Students construct their knowledge in such environment in order to solve everyday life problems. Constructivist classroom setting motivates students towards lesson and contributes significantly to attracting their interest in a given subject [59]. Consideration of affective characteristics in learning environment may be perceived as a factor that enhances the effect size of constructivist approach.

Active learning and multiple intelligences theories have become prominent along with constructivism in redesigned curricula in Turkey [49]. These concepts are based on student-centered learning, which considers individual needs and helps students with constructing the learning process suitably for them [1]. New information should be assimilated, meaning should be given to it and it should meet every day needs of individual. Student-centered teaching plays an important role in the acquisition of these features [23]. This type of teaching seeks to educate individuals who use information rather than memorizing it, by preparing students to life. While doing so, it transforms the role of information transferor of teacher into the role of guide.

Student-centered approach, which constitutes the basis for new primary education curriculum, assigns teacher as a guide and the emphasis has shifted from 'teaching' to 'learning'. Learning process is currently being structured in line with the interests, desires, expectations, skills and needs of students. It has revealed the profile of a student who has acquired language skills, communicates effectively, participates in group studies, uses verbal and body language effectively and is highly self-confident. Upon easing the subjects of lesson content and enriching it with activities, it has been sought to make lessons student-centered [28]; [45]; [69]. Lessons, which have been designed in this way, are intended for educating individuals who acquire the skill of scientific teaching, learn to learn, use information actively, communicate effectively, adopt universal values, follow and use technologic developments and realize themselves [50]. This requires student-centered learning to be present in learning environments [48].

It is important for Turkish teachers to have rich methods and techniques available for achievement of objectives in Turkish curriculum and instilling knowledge, skills and attitudes specified in the curriculum at students effectively [22]. Turkish lesson is addressed at a broad field as it improves basic language skills, raises mother tongue awareness and affects learning other subjects. Therefore, it is important that different methods and techniques are employed in the learning process [21]. A good Turkish teacher should know potential methods to be used in the lesson, their benefits, limitations and ways of effectively using these [55]. To this end, teacher initially needs to have in-depth knowledge on the class. Because each student has a different learning style and learns accordingly [64]. Teacher helps students with their learning in accordance with their individual characteristics by closely recognizing students with characteristics that are different from each other.

Language teaching methods aim for enabling individuals to effectively intercommunicate and to acquire the necessary traits rapidly and successfully in accordance with the developments and conditions of the age [55]. Turkish Instruction Curriculum evaluates methods, techniques and strategies as instruments for accessing to attainment. Teachers are expected to guide students as necessary in learning environments in relation to teaching methods, techniques and strategies, and effectively using these in order for students to improve their language skills [51]. Teachers guide students and teach them the ways to access information for students to attain the targeted contents. Methods should be determined in scope of a predetermined plan to this end.

Formulation of plans and determination of methods in relation to ensuring that students comprehend a given subject facilitates teaching, and saves time and energy. Therefore, it is utterly necessary to make plans and determine the method and technique to be employed for each lesson in advance [52]. Several factors such as changes in educational system, qualities, interests and needs of target audience, physical facilities and the nature of the subject affect the selection of method to be used in a lesson [55].

As Turkish is a multidimensional lesson, the use of several methods and techniques during learning enhances efficiency 
of lesson. Attention should be paid to ensure that selected methods are suitable for the perceptual capacity of student [52]. Additionally, methods and techniques should also be suitable for the content. Every method is not necessarily suitable for all skill fields of language. Each language skill has its unique characteristics. In this respect, the use of different methods and techniques in basic language skills makes learning permanent [11]. Learning with activities, learning by assimilating and learning by understanding concepts have become prominent in the methods used for Turkish language instruction [36]. Students are observed to obtain more successful results by virtue of internalization of knowledge facilitated by student-centered methods.

An integrated examination of results of practices in any area through meta-analyses used to calculate the effect size of various methods allows for going beyond the data obtained from individual studies. Any differences between previous studies may be evaluated in a healthy manner through meta-analyses. Upon relevant literature review, no study examining the results of studies in Turkish language instruction in scope of a meta-analysis was found. Even though there are certain descriptive studies in this area, no study has been conducted to calculate the effect sizes of study results. This study represents a first in its field in this respect, thus it will contribute greatly to the literature. Research results were combined in order to reveal the effect of student-centered methods on academic success.

The aim of the present study is to determine the influence of student-centered methods employed in Turkish language instruction on the academic success of students through meta-analysis. In this scope, the question is expressed as "Is there a significant difference between the student-centered methods and conventional education in Turkish language instruction?"

Sub-questions of the research are as follows: (i) What is the effect size of multiple intelligences based learning on the academic success of students in Turkish language instruction? (ii) What is the effect size of creative drama based learning on the academic success of students in Turkish language instruction? (iii) What is the effect size of collaborative learning on the academic success of students in Turkish language instruction? (iv) What is the effect size of game based learning on the academic success of students in Turkish language instruction?

\section{Method}

The current study has been conducted through meta-analysis method. Meta-analysis, which is used to combine the results of similar studies conducted in any given subject [26] effectively integrates and interprets the results of studies carried out on a specific area. In addition to literature review, meta-analysis also involves the design of new studies on the same or a similar subject [4].

\subsection{Procedure}

- Literature review was made in order to determine the experimental studies on Turkish language instruction,

- Studies to be included in the meta-analysis were determined as a result of the review,

- Determined studies were coded in accordance with the coding form,

- Number of persons, arithmetic mean and standard deviation of reviewed studies were analyzed on CMA program,

- Fixed effect sizes were calculated in accordance with research methods,

- Analysis was conducted based on random effects model due to heterogeneity of the data,

- Obtained findings were set out in tables and interpreted,

- Obtained findings were discussed.

\subsection{Data Collection}

Criteria for inclusion: Experimental studies conducted between 2000 and 2016 in relation to the effect of student-centered methods on Turkish language instruction were examined in order to determine the effects of multiple intelligences-based learning, creative drama-based learning, collaborative learning and game-based learning on the academic success in Turkish lesson.

Master's theses, doctorate theses, articles and papers on the area of Turkish language instruction were included in the scope of the research. Thesis center of Council of Higher Education was principally used to access these resources. Relevant authors of theses to which access was blocked at thesis center were contacted in an attempt to acquire such theses. National and international databases such as EBSCO, ERIC, ASOS Index and ULAKBIM, and Google Scholar search engine were used to access the articles. Reviews were made in a bidirectional manner both in the context of Turkish language instruction area and studies addressed at the methods in question. Even though the keywords were searched both in Turkish and English, only a limited number of studies were found in English. Keywords such as Turkish language instruction, Turkish education, Turkish language instruction experimental, multiple intelligences, multiple intelligences-based learning, creative drama, creative drama-based learning, collaborative learning, collaboration learning, collaboration-based learning, game-based learning, teaching with games were used during the review. Additionally, the keywords used in relation to these methods were also searched together with the concept of Turkish language instruction.

Experimental and quasi-experimental studies were selected for meta-analysis. Relevant studies which did not qualify as experimental research, did not examine the effect of teaching methods on academic success and did not present the statistical data required for effect size (sample size, arithmetic mean, standard deviation) were excluded 
from the study. 96 studies relating to the use of multiple intelligences-based learning, creative drama-based learning, collaborative learning and game- based learning in Turkish language instruction were determined; and the studies among these, which had experimental-control groups were included in the meta-analysis. Certain studies were excluded from the meta-analysis as these did not have the data used in the meta-analysis (lack of total data, standard deviation, sample size). Due to these reasons, the sample of the study is comprised of 22 studies. Studies on multiple intelligences-based learning $(\mathrm{f}=5)$, creative drama-based learning $(\mathrm{F}=6)$, collaborative learning $(\mathrm{F}=6)$ and game-based learning $(\mathrm{f}=5)$ were used. Attention was paid to ensure the availability of at least 5 studies for each student-centered method in Turkish language instruction. As a minimum of five comparisons are required for the reliability of Hedge's d used in the effect size calculation (Rosenberg et al., 2000, cited in: [8], methods that did not meet the minimum number were excluded from the evaluation.

Criteria for inclusion of the studies in the current research are as follows:

It should be an experimental study examining the effects of student-centered methods on Turkish language instruction,

The study should measure the effect of multiple intelligences-based learning, creative drama-based learning, collaborative learning and game-based learning in Turkish language instruction on academic success.

At least five studies should be available for the relevant method.

The study should contain the statistical data (sample size, arithmetic mean, standard deviation) used in effect size calculation.

Dependent variables: As the dependent variables of the study, effect sizes of student-centered methods used in the studies included in meta-analysis on the academic success in Turkish language instruction were determined. Effect sizes are standardized values for different measurement tools in relation to each study [63].

Academic success scores in the studies included in the meta-analyses were determined with success tests developed by researchers. Effect sizes, which were calculated with the help of the scores obtained from success tests used in the studies, present standardized values for measurement tools that differ in each study [20].

Study characteristics: In the current study researching the effect of student-centered methods employed in Turkish language instruction on academic success, general characteristics of examined 22 studies and their respective effect sizes were determined. Post-test results of the analyzed studies were compared in scope of the research.

Details on the methods, publication type, date of publication, subject of publication and educational level of studies examined in scope of the research are given in Table 1 :

Table 1. Frequencies and Percentages of Study Characteristics

\begin{tabular}{|c|c|c|c|}
\hline Variable & & $\mathrm{f}$ & $\%$ \\
\hline \multirow{4}{*}{ Method } & Multiple intelligences-based learning & 5 & 22,7 \\
\hline & Creative drama-based learning & 6 & 27,3 \\
\hline & Collaborative learning & 6 & 27,3 \\
\hline & Game-based learning & 5 & 22,7 \\
\hline \multirow{4}{*}{ Type of publication } & Doctorate thesis & 3 & 13,6 \\
\hline & Master's thesis & 11 & 50 \\
\hline & Article & 7 & 31,8 \\
\hline & Paper & 1 & 4,5 \\
\hline \multirow{3}{*}{ Year of publication } & $2006-2008$ & 5 & 22,7 \\
\hline & 2009-2012 & 9 & 40,9 \\
\hline & 2013-2014 & 8 & 36,4 \\
\hline \multirow{6}{*}{ Subject of Publication } & Reading & 5 & 22,7 \\
\hline & Writing & 3 & 13,6 \\
\hline & Teaching vocabulary & 5 & 22,7 \\
\hline & Grammar & 4 & 18,2 \\
\hline & Speaking & 1 & 4,5 \\
\hline & Mixed language skills & 4 & 18,2 \\
\hline \multirow{3}{*}{ Educational Level } & Primary education & 17 & 77,2 \\
\hline & University & 2 & 9,1 \\
\hline & Foreign nationals & 3 & 13,6 \\
\hline
\end{tabular}


Studies included in the meta-analysis employed the methods of multiple intelligences based learning (5), creative drama based learning (6), collaborative learning (6) and game-based learning (5). In respect to the types of publication, the majority of the studies were comprised of master's degree theses (11) and the studies were distributed among different years of publication, and as for subject of publication, various language skills were addressed in a mixed manner whereas in respect to educational level, the studies were mostly focused on primary education level (17).

Validity and reliability study for the coding process: A coding form was developed in order to determine the suitability of studies selected in scope of the meta-analysis with the criteria for inclusion. The developed coding form is important in respect to determination of the variables used in comparisons between different meta-analyses. Coding form contributes to researcher in respect to easily accessing data. Coding form should be sufficiently generalized to include all studies and specific to the extent necessary to reveal study differences [18]. In this sense, a coding form was attempted to be developed in relation to the studies included in the meta-analysis. Code of study, name of study, name of author, method used in study, type of study, year of publication, subject of study and educational level are included in the coding form.

Coding process was followed with the coding form in the meta-analysis. Certain descriptive data about the form are presented. Literature review was conducted as relevant and meta-analysis coding forms were determined during the coding process [6]; [12]; [16]; [30]; [65]. Determined coding forms were examined in order to develop a coding form suitable for the characteristics of the current study.

Studies were also examined by an independent second coder who filled out the article evaluation form for the reliability calculation of the coding form. Completed forms were compared to calculate the reliability ratio of coding forms of the first coder to the second coder. The formula by [53] [agreement / (agreement + disagreement) x 100] was used for the calculation of reliability rate, which resulted to be $100 \%$ for the current study.

\subsection{Data Analysis}

Initially effect sizes were determined during the analysis of the studies included in the meta-analysis. "Hedges'd" was used for effect size calculation. Effect size is calculated by converting arithmetic mean, standard deviation, $t, F$ or $r$ values of studies into a standard measurement value (Rosenthal, 1991, cited in: [42].

(Comprehensive Meta-Analysis CMA) program was used in the calculation of combined effect size scores of the studies employing the methods in scope of the meta-analysis. Mean posttest, sample group, standard deviation and certain statistical scores (F, t, $\mathrm{z}, \mathrm{Q}$ etc.) were determined for the experimental and control groups while calculating the effect sizes with the program. Furthermore, chi-square test of homogeneity $(\mathrm{Q})$ with degrees of freedom was used to determine whether studies were heterogeneous. The homogeneity test result indicated that studies had a heterogeneous distribution with significant effect sizes. Therefore, effect sizes were determined according to random effects model. Thus mean posttest, sample group, standard deviation scores and certain statistical scores $(\mathrm{F}, \mathrm{t}$, $z$, Q etc.) of the studies included in the meta-analysis were used. Furthermore, the program SPSS 17.0 was used to analyze descriptive data and Microsoft Excel 2010 was used to enter the data into the coding form.

[13] classification was used for mean effect sizes. Effect size ranges according to [13] are listed as follows:

$$
\begin{aligned}
& 0.20-0.50 \text { small } \\
& 0.50-0.80 \text { medium } \\
& 0.80<\text { large }
\end{aligned}
$$

\section{Results}

The analysis results of the data of the studies examining the effect of multiple intelligences-based learning in Turkish language instruction on academic success are given in Table

\begin{tabular}{|c|c|c|c|c|c|c|c|c|}
\hline \multirow{2}{*}{ Model Type } & \multirow{2}{*}{$\mathrm{N}$} & \multirow{2}{*}{$\mathrm{Z}$} & \multirow{2}{*}{$\mathrm{P}$} & \multirow{2}{*}{ Q } & \multirow{2}{*}{ ES } & \multirow{2}{*}{ SE } & \multicolumn{2}{|c|}{ 95\% Confidence Interval } \\
\hline & & & & & & & Lower & Upper \\
\hline FEM & 5 & 10.203 & .000 & 29.839 & 1.302 & .128 & 1.052 & 1.553 \\
\hline REM & 5 & 3.770 & .000 & 3.870 & 1.332 & .353 & .640 & 2.024 \\
\hline
\end{tabular}
2.

Table 2. Mean Effect Size and Homogeneity Scores of Multiple Intelligences-Based Learning According to Fixed Effects Model 
As a result of the fixed effects model analysis conducted to determine the effect of learning based on multiple intelligences theory on Turkish language instruction, Table 2 reveals that standard error margin is 0.128 , lower boundary of $95 \%$ confidence interval is 1.052 and its upper boundary is 1.553. Upon comparison of multiple intelligences-based learning with a mean effect size score of 1.302 to conventional teaching method, it is observed that it has a greater effect on the academic success of students. The effect size is large in accordance with [13] classification. The result of $\mathrm{z}$-test, conducted to determine statistical significance of the data, was $z=10.203$. The result with $p=0.000$ indicates that the analysis is statistically significant. The homogeneity test resulted in $\mathrm{Q}=29.839 . \chi^{2}$ table revealed that 4 degrees of freedom with $95 \%$ significance level had a score of 9.488. As $\mathrm{Q}=29.839$ score exceeds the critical score of chi-square distribution in 4 degrees of freedom $\left(\chi_{(0.95)}^{2}=9.488\right)$ it was determined that the effect sizes of the studies were heterogeneous in accordance with the fixed effects model analysis. Due to the heterogeneity of the distribution, analyses were made in accordance with random effects model for clarification(Y1ld1z, 2002, cited in: [7]. Thus, the effect of multiple intelligences-based learning on academic success was calculated in accordance with random effects model.

As a result of the random effects model analysis, it is observed that standard error margin is 0.353 , lower boundary of $95 \%$ confidence interval is 0.640 and its upper boundary is 2.024. Upon comparison of multiple intelligences-based learning with a mean effect size score of 1.332 to conventional teaching method, it is observed that it has a greater effect on the academic success of students. The effect size is large in accordance with [13] classification. The result of $\mathrm{z}$-test, conducted to determine statistical significance of the data, was $z=3.770$. The result with $p=0.000$ indicates that the analysis is statistically significant. The homogeneity test resulted in $\mathrm{Q}=29.839 . \chi^{2}$ table revealed that 4 degrees of freedom with $95 \%$ significance level had a score of 9.488 . $\mathrm{Q}=3.870$ score did not exceed the critical score of chi-square distribution in 4 degrees of freedom $\left(\chi_{(0.95)}^{2}=9.488\right)$.

The analysis results of the data of the studies examining the effect of creative drama-based learning in Turkish language instruction on academic success are given in Table 3 :

Table 3. Mean Effect Size and Homogeneity Scores of Creative Drama-Based Learning According to Fixed Effects Model

\begin{tabular}{|c|c|c|c|c|c|c|c|c|}
\hline \multirow{2}{*}{ Model Type } & \multirow{2}{*}{$\mathrm{N}$} & \multirow{2}{*}{ Z } & \multirow{2}{*}{$\mathrm{P}$} & \multirow{2}{*}{ Q } & \multirow{2}{*}{ ES } & \multirow{2}{*}{ SE } & \multicolumn{2}{|c|}{$95 \%$ Confidence Interval } \\
\hline & & & & & & & Lower & Upper \\
\hline FEM & 6 & 7.050 & .000 & 86.310 & .920 & .130 & .664 & 1.176 \\
\hline REM & 6 & 3.003 & .003 & 10.299 & 1.712 & .570 & .595 & 2.830 \\
\hline
\end{tabular}

Table 4. Mean Effect Size and Homogeneity Scores of Collaborative Learning According to Fixed Effects Model

\begin{tabular}{|c|c|c|c|c|c|c|c|c|}
\hline \multirow{2}{*}{ Model Type } & \multirow{2}{*}{$\mathrm{N}$} & \multirow{2}{*}{$\mathrm{Z}$} & \multirow{2}{*}{$\mathrm{P}$} & \multirow{2}{*}{ Q } & \multirow{2}{*}{ ES } & \multirow{2}{*}{ SE } & \multicolumn{2}{|c|}{ 95\% Confidence Interval } \\
\hline & & & & & & & Lower & Upper \\
\hline FEM & 6 & 7.386 & .000 & 15.171 & .782 & .106 & .575 & .990 \\
\hline REM & 6 & 4.342 & .000 & 4.563 & .816 & .188 & .448 & 1.184 \\
\hline
\end{tabular}


As a result of the fixed effects model analysis conducted to determine the effect of collaborative learning on Turkish language instruction, Table 4 reveals that standard error margin is 0.106 , lower boundary of $95 \%$ confidence interval is 0.575 and its upper boundary is 0.990 . Upon comparison of collaborative learning with a mean effect size score of 0.782 to conventional teaching method, it is observed that it has a greater effect on the academic success of students. The effect size is medium in accordance with [13] classification. The result of z-test, conducted to determine statistical significance of the data, was $z=7.386$. The result with $p=0.003$ indicates that the analysis is statistically significant. The homogeneity test resulted in $Q=15.171$. $\mathrm{X}^{2}$ table revealed that 5 degrees of freedom with $95 \%$ significance level had a score of 11.070. As $Q=15.171$ score exceeds the critical score of chi-square distribution in 5 degrees of freedom $\left(\chi_{(0.95)}^{2}=11.070\right)$ it was determined that the effect sizes of the studies were heterogeneous in accordance with the fixed effects model analysis. Due to the heterogeneity of the distribution, analyses were made in accordance with random effects model for clarification (Y1ldiz, 2002, cited in: [7]. Thus, the effect of collaborative learning on academic success was calculated in accordance with random effects model.

As a result of the random effects model analysis, it is observed that standard error margin is 0.188 , lower boundary of $95 \%$ confidence interval is 0.448 and its upper boundary is 1.184. Upon comparison of collaborative learning with a mean effect size score of 0.816 to conventional teaching method, it is observed that it has a greater effect on the academic success of students. The effect size is large in accordance with [13] classification. The result of z-test, conducted to determine statistical significance of the data, was $z=4.342$. The result with $\mathrm{p}=0.000$ indicates that the analysis is statistically significant. The homogeneity test resulted in $\mathrm{Q}=15.171 . \chi^{2}$ table revealed that 5 degrees of freedom with $95 \%$ significance level had a score of $11.070 . \mathrm{Q}=4.563$ score did not exceed the critical score of chi-square distribution in 5 degrees of freedom $\left(\chi_{(0.95)}^{2}=11.070\right)$.

The analysis results of the data of the studies examining the effect of game-based learning in Turkish language instruction on academic success are given in Table 5:
As a result of the fixed effects model analysis conducted to determine the effect of game-based learning on Turkish language instruction, Table 5 reveals that standard error margin is 0.140 , lower boundary of $95 \%$ confidence interval is 0.984 and its upper boundary is 1.531 . Upon comparison of game-based learning with a mean effect size score of 1.258 to conventional teaching method, it is observed that it has a greater effect on the academic success of students. The effect size is large in accordance with [13] classification. The result of z-test, conducted to determine statistical significance of the data, was $z=9.009$. The result with $p=0.000$ indicates that the analysis is statistically significant. The homogeneity test resulted in $\mathrm{Q}=40.566 . \chi^{2}$ table revealed that 4 degrees of freedom with $95 \%$ significance level had a score of 9.488. As $Q=40.566$ score exceeds the critical score of chi-square distribution in 4 degrees of freedom $\left(\chi_{(0.95)}^{2}=9.488\right)$ it was determined that the effect sizes of the studies were heterogeneous in accordance with the fixed effects model analysis. Due to the heterogeneity of the distribution, analyses were made in accordance with random effects model for clarification (Yildı, 2002, cited in: [7]. Thus, the effect of game-based learning on academic success was calculated in accordance with random effects model.

As a result of the random effects model analysis, it is observed that standard error margin is 0.140 , lower boundary of $95 \%$ confidence interval is 0.642 and its upper boundary is 2.434. Upon comparison of game-based learning with a mean effect size score of 1.538 to conventional teaching method, it is observed that it has a greater effect on the academic success of students. The effect size is large in accordance with [13] classification. The result of z-test, conducted to determine statistical significance of the data, was $z=3.365$. The result with $\mathrm{p}=0.001$ indicates that the analysis is statistically significant. The homogeneity test resulted in $\mathrm{Q}=5.412 . \chi^{2}$ table revealed that 4 degrees of freedom with $95 \%$ significance level had a score of 9.488. Q=5.412 score did not exceed the critical score of chi-square distribution in 5 degrees of freedom $\left(\chi_{(0.95)}^{2}=9.488\right)$.

Table 5. Mean Effect Size and Homogeneity Scores of Game-Based Learning According to Fixed Effects Model

\begin{tabular}{|c|c|c|c|c|c|c|c|c|}
\hline $\begin{array}{c}\text { Model } \\
\text { Type }\end{array}$ & $\mathrm{N}$ & $\mathrm{Z}$ & $\mathrm{P}$ & $\mathrm{Q}$ & ES & SE & \multicolumn{2}{|c|}{$95 \%$ Confidence Interval } \\
\hline FEM & 5 & 9.009 & .000 & 40.566 & 1.258 & .140 & .984 & Lower \\
\hline REM & 5 & 3.365 & .001 & 5.412 & 1.538 & .457 & .642 & 2.434 \\
\hline
\end{tabular}


As the size effect score yielded from fixed effect analysis was $\mathrm{ES}=1.302$, it was observed that it was in favor of the multiple intelligences-based learning in Turkish language instruction. It was determined that the data did not reflect the entire study population as the studies were revealed to be heterogeneous based on the homogeneity test ( $\mathrm{Q}$ test) [34]. According to this result, calculations were made through random effects model as necessary. As a result of the random effects model analyses, it was observed that standard error margin is 0.353 , lower boundary of $95 \%$ confidence interval is 0.640 and its upper boundary is 2.024 . Effect size score was calculated to be $\mathrm{ES}=1.332$. This score is positively and significantly large in accordance with [13] classification. The results of the studies on the effect of multiple intelligences-based learning on Turkish language instruction reaffirm the studies examining the effect of this method on academic success. [2]; [14]; [24]; [43]; [44]; [46] etc. also determined in their studies that multiple intelligences-based learning $\mathrm{n}$ Turkish language instruction had a greater effect on the student success than conventional teaching method. It is also observed in the meta-analyses examining the relation of multiple intelligences-based learning to other disciplines [8]; [41] that this method positively affects student success as compared to conventional teaching method.

Effect size of creative drama-based learning in Turkish language instruction according to fixed effects model was calculated to be $\mathrm{ES}=0.920$. It was determined that the data did not reflect the entire study population as the studies were revealed to be heterogeneous based on the homogeneity test (Q test) [34]. According to this result, calculations were made through random effects model as necessary. As a result of the random effects model analyses, it was observed that standard error margin is 0.570 , lower boundary of $95 \%$ confidence interval is 0.595 and its upper boundary is 2.830 . Effect size score was calculated to be ES $=1.712$. This score is positively and significantly large in accordance with [13] classification. Results of the study about the effect of creative drama on Turkish language instruction also coincide with individual studies examining the effect of creative drama on the academic success in Turkish lesson. [3]; [15]; [39]; [57]; [66]; [72] etc. also determined in their studies that creative drama-based learning in Turkish language instruction had a greater effect on the student success than conventional teaching method. However, [58] determined that creative drama-based learning did not affect the success of students to an extent which yields a significant difference as compared to the conventional teaching method. It is also observed in the meta-analyses examining the relation of creative drama-based learning to other disciplines [5]; [47]; [67] that this method positively affects student success as compared to conventional teaching method.

As the size effect score yielded from fixed effect analysis was $\mathrm{ES}=0.782$, it was observed that it was in favor of the collaborative learning in Turkish language instruction. It was determined that the data did not reflect the entire study population as the studies were revealed to be heterogeneous based on the homogeneity test ( $Q$ test) [34]. According to this result, calculations were made through random effects model as necessary. As a result of the random effects model analysis, it was observed that standard error margin is 0.188 , lower boundary of $95 \%$ confidence interval is 0.448 and its upper boundary is 1.184. Effect size score was calculated to be $\mathrm{ES}=0.816$. This score is positively and significantly large in accordance with [13] classification. The results of the studies on the effect of collaborative learning on Turkish language instruction reaffirm the studies examining the effect of this method on academic success. [10], [17], [32], [37], [73] etc. researchers also determined that collaborative learning in Turkish language instruction have a greater effect on student success as compared to conventional teaching method. It is also observed in the meta-analyses examining the relation of collaborative learning to other disciplines [38]; [60] that this method positively affects student success as compared to conventional teaching method.

Effect size of game-based learning in Turkish language instruction according to fixed effects model was calculated to be $\mathrm{ES}=1.258$. It was determined that the data did not reflect the entire study population as the studies were revealed to be heterogeneous based on the homogeneity test (Q test) [34]. According to this result, calculations were made through random effects model as necessary. As a result of the random effects model analysis, it was observed that standard error margin is 0.140 , lower boundary of $95 \%$ confidence interval is 0.642 and its upper boundary is 2.434 . Effect size score was calculated to be $\mathrm{ES}=1.538$. This score is positively and significantly large in accordance with [13] classification. The results of the studies on the effect of game-based learning on Turkish language instruction reaffirm the studies examining the effect of this method on academic success. [19], [27], [31], [61], [70] etc. also determined in their studies that game-based learning in Turkish language instruction had a greater effect on the student success than conventional teaching method.

The current study brings experimental studies together. Studies which also examine relational studies in scope of meta-analysis may prove useful in respect to indication of effect rates of such studies in Turkish language instruction.

It was observed in the reviewed 96 studies that the success tests are not standardized. The use of standard tests instead of these tests with different qualities may improve validity and reliability of data.

Statistical tests used in the studies were conducted differently from each other with a quite dispersed structure. Lack of total data or specification of standard deviation, arithmetic mean and sample size prevent these studies to be included in meta-analysis. Data obtained from 16 studies were excluded from the current study only due to the lack of total data. In addition to other specified issues, a considerable quantity of studies was excluded due to failure 
to meet the meta-analysis criteria. It is highly important to write statistical operations in conformity to international standards for these issues to be overcome.

In the current meta-analysis study, the effect of student-centered teaching methods employed in Turkish language instruction on academic success of students was examined. Other meta-analyses examining factors such as attitude instead of academic success may also be conducted on these subjects.

Studies researching the effect of different teaching methods in Turkish language instruction on the academic success of student may also be carried out.

Meta-analytic dimension of the current study may be advanced to further dimensions and broadened for future research. This advancement may be realized in scope of a pluralist holistic approach defined as the use of different analysis programs together under a study and the combination of the results with a holistic understanding in accordance with methodological pluralism [9]. Considering that the studies to be designed with this approach may yield more extensive and reliable results, these studies are suggested.

\section{REFERENCES}

Studies marked with asterisk $\left(^{*}\right)$ are included in the meta-analysis.

[1] Akpınar, Y. (1999). Bilgisayar Destekli Öğretim ve Uygulamalar. Ankara: Anı Yayıncılık.

[2] *Arıci, B. (2012). Çoklu zekâ destekli Türkçe dersi sunumunun ilköğretim sekizinci sınıf öğrencilerinin fiilimsileri kavrama durumlarına etkisi. Yayınlanmamış yüksek lisans tezi, Karadeniz Teknik üniversitesi, Trabzon.

[3] *Aykaç, M. ve Çetinkaya, G. (2013). Yaratıcı drama etkinliklerinin Türkçe öğretmen adaylarının konuşma becerilerine etkisi. Turkish Studies, 8(9), 671-682.

[4] Başol Göçmen, G. (2004). Meta analizin genel bir değerlendirmesi. Sakarya Üniversitesi Eğitim Fakültesi Dergisi, 7, 209-214.

[5] Batd1, V. \& Batd1, H. (2015). Effect of creative drama on academic achievement: A meta-analytic and thematic analysis. Educational Sciences: Theory \& Practice, 15(6), 1459-1470.

[6] Batdı, V. (2014a). Harmanlanmış öğrenme ortamlarının öğrencilerin akademik başarılarına etkisi: Bir meta analiz çalıșması. Çankırı Karatekin Üniversitesi Sosyal Bilimler Enstitüsü Dergisi, 5(1), 287-302.

[7] Batdı, V. (2014b). Jigsaw tekniğinin öğrencilerin akademik başarılarına etkisinin meta analiz yöntemiyle incelenmesi. Ekev Akademi Dergisi, 18(58), 699-714.

[8] Batd1, V. (2015). A meta-analytic study concerning the effect of computer-based teaching on academic success in Turkey. Educational Sciences: Theory \& Practice, 15(5), 1271-1286.

[9] Batdı, V. (2016, May). Metodolojik çoğulculukta yeni bir yönelim: trend programlarla çoklu bütüncül bir yaklaşım. 7th
International Congress on New Trends in Education (ICONTE), Antalya, Türkiye.

[10] Bayburtlu, Y. S. (2015). İşbirliğine dayalı öğrenme yaklaşımının 6. sınıf Türkçe dersi kazanımlarına etkileri. Turkish Studies, 10(11), 235-274.

[11] Calp, M. (2010). Özel Eğitim Alanı Olarak Türkçe Öğretimi. Ankara: Nobel Dağıtım.

[12] Camnalbur, M. (2008). Bilgisayar destekli öğretimin etkililiği üzerine bir meta analiz çalışması. Yayınlanmamış yüksek lisans tezi, Marmara üniversitesi, İstanbul.

[13] Cohen, J. (1992). Statistical power analysis. Current Directions in Psychological Science, 1(3), 98-101.http://courses.csusm.edu/psyc393md/2011-Fall-41892 /readings/StatisticalPower/Cohen\%281992\%29StatisticalPow er.pdf adresinden edinilmiştir.

[14] *Cayır, N. B. (2011). İlköğretim 4. sınıf Türkçe dersi öğretiminde çoklu zekâ uygulamalarının öğrencilerin okuduğunu anlama ve yazılı anlatım becerileriyle ilgili deneysel bir araştırma. Yayınlanmamış yüksek lisans tezi, Dokuz Eylül üniversitesi, İzmir.

[15] Çebi, A. (2008 Şubat). İlköğretim ikinci aşamada yaratıcı drama destekli bilgisayar okuryazarlığı. Akademik Bilişim, Çanakkale, Türkiye.

[16] Çelik, S. (2013). İlköğretim matematik derslerinde kullanılan alternatif öğretim yöntemlerinin akademik başarıya etkisi: bir meta analiz çalışması. Yayınlanmamış yüksek lisans tezi, Eskişehir Osmangazi üniversitesi, Eskişehir.

[17] *Çörek, D. (2006). İşbirlikli Öğrenmenin Türkçe dersine ilişkin başarı ve derse yönelik tutum üzerindeki etkileri. Yayınlanmamıs yüksek lisans tezi, Dokuz Eylül üniversitesi, İzmir.

[18] Dağyar, M. ve Demirel, M. (2015). Probleme dayalı öğrenmenin akademik başarıya etkisi: Bir meta analiz çalışması. Eğitim ve Bilim, 40(181), 139-174.

[19] *Dervişoğulları, N. (2008). Yabancı dil olarak Türkçe öğretilen sinıflarda oyunlarla sözcük öğretimi. Yayınlanmamış yüksek lisans tezi, Ankara üniversitesi, Ankara.

[20] Demir, S. ve Başol, G. (2014). Bilgisayar destekli matematik öğretiminin (BDMÖ) akademik başarıya etkisi: Bir metaanaliz çalışması. Educational Sciences: Theory \& Practice, 14(5), 2013-2035.

[21] Demirel, Ö. (1998). Türkçe öğretimde çağdaş öğretim yöntem ve teknikleri. (Ed. S. Topbaş). Türkçe Ögretimi kitabı içinde (s. 37-52). Eskişehir: Açıköğretim Fakültesi Yayınları.

[22] Demirel, Ö. (2006). Kuramdan Uygulamaya Eğitimde Program Geliştirme. Ankara: PegemA Yayıncılık.

[23] Dönmez, İ. (2008). İlköğretim fen ve teknoloji dersi öğrenme ortamlarının öğrenci merkezli eğitim açısından değerlendirilmesi. Yayınlanmamış yüksek lisans tezi, Osmangazi üniversitesi, Eskişehir.

[24] *Epçaçan, C. (2013). Çoklu zekâ kuramına dayalı öğretim uygulamalarının öğrencilerin okuduğunu anlama becerilerine etkisi. Turkish Studies, 8(1), 1335-1353.

[25] Epçaçan, C. ve Erzen, M. (2008). İlköğretim Türkçe dersi 
öğretim programının değerlendirilmesi. Uluslararası Sosyal Araştırmalar Dergisi, 1(4), 182-202.

[26] Ergene, T. (2003). Sinav kaygısını azaltma programlarının etkililiği: Bir meta analiz çalışması. VII. Ulusal Psikolojik Danışma ve Rehberlik Kongresi, Malatya.

[27] Gedik, M. (2012). Ortaokul ikinci sınıf öğrencilerinin temel dil becerilerinin geliştirilmesinde eğitsel oyunların başarı ve kalıcılığa etkileri. Yayınlanmamış doktora tezi, Atatürk üniversitesi, Erzurum.

[28] Gömleksiz, M. N. ve Kan, A. Ü. (2007). Yeni ilköğretim programlarının dayandığı temel ilke ve yaklaşımlar. Doğu Anadolu Bölgesi Araştırmaları, 5(2), 60-66.

[29] *Gözalan, E. ve Koçak, N. (2014). Oyun temelli dikkat eğitim programının 5-6 yaş çocukların kelime bilgi düzeylerine etkisinin incelenmesi. KMÜ Sosyal ve Ekonomik Araştırmalar Dergisi, 16 (Özel Sayı II), 115-121.

[30] Gözüyeşil, E. (2012). Beyin temelli öğrenmenin akademik başarıya etkisi: Bir meta analiz çalışması. Yayınlanmamış yüksek lisans tezi, Niğde üniversitesi, Niğde.

[31] *Gülsoy, T. ve Uçgun, D. (2013). 6. sınıf öğrencilerinin kelime hazinesinin geliştirilmesinde eğitsel oyunların etkisinin incelenmesi. Turkish Studies, 8(13), 943-952.

[32] *Gümüş, O. (2006). İşbirliğine dayalı öğrenme yaklaşımının ilköğretim dördüncü sınıf Türkçe dersi hedeflerinin kazandırılması ve öğrenci başarısına etkisi. Yayınlanmamış yüksek lisans tezi, Gazi üniversitesi, Ankara.

[33] Gümüş, O. ve Buluç, B. (2007). İşbirliğine dayalı öğrenme yaklaşımının Türkçe dersinde akademik başarıya etkisi ve öğrencilerin derse ilgisi. Kuram ve Uygulamada Eğitim Yönetimi, 49, 7-30.

[34] Günay, R., Kaya, Y. ve Aydın, H. (2014). Çokkültürlü eğitim yaklaşımının etkililik düzeyi: Bir meta-analiz çalışması. Uşak Üniversitesi Sosyal Bilimler Dergisi, 7(4), 145-166.

[35] Güneş, F. (2014a). Türkçe Öğretimi-Yaklaşımlar ve Modeller. Ankara: Pegem Akademi.

[36] Güneş, F. (2014b). Tanım ve kavramlar. (Ed. F. Güneş). Öğretim İlke ve Yöntemleri içinde (s. 1-22). Ankara: Pegem Yayıncilık.

[37] Güngör, A. ve Ün Açıkgöz, K. (2005). İşbirlikli öğrenme ve geleneksel öğretimin okuduğunu anlama üzerinde etkileri ve cinsiyet ile ilişkileri. Kuram ve Uygulamada Eğitim Yönetimi, 43, 354-378.

[38] Johnson, D. W., Johnson, R. T. and Stanne, M. B. (2000). Cooperative learning methods: A meta-analysis.https://www. researchgate.net/publication/220040324 Cooperative Learni ng_Methods_A_Meta-Analysis adresinden alınmıştır.

[39] *Karacil, M. (2009). İlköğretim 1. kademede yaratıcı drama yönteminin öğrencinin akademik başarısına etkisi. Yayınlanmamış yüksek lisans tezi, Kafkas üniversitesi, Kars.

[40] *Kardaş, M. N. (2013). İş birlikli öğrenme yönteminin sınıf öğretmeni adaylarının yazılı anlatım becerilerine etkisi. Turkish Studies, 8(9), 1781-1799.

[41] Kaplan, A., Duran, M. ve Baş, G. (2015). Matematik dersinde çoklu zekâ kuramına dayalı öğretimin akademik bașarıya etkisi: Bir meta analiz çalışması. Mersin Üniversitesi Eğitim Fakültesi Dergisi, 11(3): 814-831.
[42] Kaşarc1, İ. (2013). Proje tabanlı öğrenme yaklassımının öğrencilerin akademik başarı ve tutumlarına etkisi: bir meta analiz çalışması. Yayınlanmamış yüksek lisans tezi, Eskişehir Osmangazi üniversitesi, Eskişehir.

[43] Kılınç, S. (2008). İlköğretim 8. sınıf Türkçe dersi uygulamalarında çoklu zeka ile sunuş yönteminin öğrenci başarısındaki etkisi. Yayınlanmamış yüksek lisans tezi, Dokuz Eylül üniversitesi, İzmir.

[44] *Kolaç, E. (2008). Çoklu zeka temelli işbirliğine dayalı öğrenme yönteminin ilkokuma öğretiminde uygulanabilirliği. Yayınlanmamış doktora tezi, Anadolu üniversitesi, Eskişehir.

[45] Kurudayığlu, M. ve Özdem, A. (2015). Türkçe öğretiminde drama. Ana Dili Eğitimi Dergisi, 3(4), 26-40.

[46] *Kuşdemir Kayıran, B. (2007). Çoklu zekâ kuramı destekli kubaşı öğrenme yönteminin Türkçe dersine ilişkin tutum ve okuduğunu anlamaya yönelik akademik başarı üzerindeki etkisi. Yayınlanmamış yüksek lisans tezi, Çukurova üniversitesi, Adana.

[47] Lee, B. K., Patall, E. A., Cawthon S. W. and Steingut, R. R. (2014). The effect of drama-based pedagogy on prek-16 outcomes a meta-analysis of research from 1985 to 2012. Review of Educational Research, 85(1), 3-49, DOI: $10.3102 / 0034654314540477$.

[48] Maden, S., Durukan, E. ve Akbaş, E. (2011). İlköğretim öğretmenlerinin öğrenci merkezli öğretime yönelik algıları. Mustafa Kemal Üniversitesi Sosyal Bilimler Enstitüsü Dergisi, $8(16), 255-269$.

[49] MoNE. (2005). İlköğretim Türkçe Öğretim Programı Ve Kılavuzu (1-5. Sinıflar). Ankara: Devlet Kitapları Basım Müdürlüğü.

[50] MoNE. (2016a). Öğrenci Merkezli Eğitim Uygulama Modeli (ÖME).http://uretim.meb.gov.tr/egitekhaber/s83/yazarlar/\%C $3 \% 96 \% \mathrm{C} 4 \% 9$ Erenc\% $\%$ C4\%B0\% 20 merkezl $\% \mathrm{C} 4 \% \mathrm{~B} 0 \% 20 \mathrm{e} \%$ C4\%9E\%C4\%B0t\%C4\%B0m.htm adresinden 25.04.2016 tarihinde alınmıştır.

[51] MoNE. (2016b). İlköğretim Türkçe Dersi (1, 2, 3, 4, 5, 6, 7 ve 8. Sınıflar) Öğretim Programı.http://ttkb.meb.gov.tr/www/ogr etim-programlari/icerik/72. adresinden 15.04.2016 tarihinde alınmıştır.

[52] Menteşe, H. (2013). Türkçe dersi öğretim programının öğretmen görüşlerine göre incelenmesi (Aydın ili örneği). Yayınlanmamış yüksek lisans tezi, Adnan Menderes üniversitesi, Aydın.

[53] Miles, M. B., \& Huberman, A. M. (1994). Qualitative Data Analysis: An Expanded Sourcebook. Thousand Oaks, California: Sage.

[54] Öz, M. F. (2006). Uygulamalı Türkçe Öğretimi. Ankara: Anı Yayıncilik.

[55] Özbay, M. (2009). Türkçe Özel Öğretim Yöntemleri I. Ankara: Öncü Basımevi.

[56] Özbay, M. (2015). Yeni Eğitim Yaklaşımlarının Türkçe Öğretiminde Uygulanması. Ankara: Öncü Basımevi.

[57] *̈̈zcan, Ş. (2013). Yaratıcı dramanın anlayarak anlatma becerilerinin geliştirilmesine etkisi. Yayınlanmamış yüksek lisans tezi, Gazi üniversitesi, Ankara. 
[58] *Selmanoğlu, E. (2009). İlköğretim 5. sınıf Türkçe dersinde yaratıcı dramanın öğrenci başarısına etkisi. Yayınlanmamış yüksek lisans tezi, Abant İzzet Baysal üniversitesi, Bolu.

[59] Şaşan, H. H. (2002). Yapılandırmacı öğrenme. Yaşadıkça Eğitim Dergisi, 74-75, 49-52.

[60] Şen, Ş. ve Yılmaz, A. (2013). İşbirlikçi öğrenmenin kavramsal değişim üzerindeki etkisi: Bir meta analiz çalışması. Karaelmas Journal of Educational Sciences, 1, 21-32.

[61] *Şentürk L. ve Aktaş E. (2013). Yabancı dil olarak Türkçenin öğretiminde oyunların başarıya etkisi, VI. Uluslararası Türkçenin Eğitimi ve Öğretimi Kurultayı, Nevşehir, Türkiye.

[62] *Şentürk, L. ve Şentürk, N. (2012). Effect of cooperative learning to teach vocabulary inTurkish as a second language course. Avrasya İncelemeleri Dergisi, I(2), 363-380.

[63] Tarım, K. (2003). Kubaşık öğrenme yönteminin matematik öğretimindeki etkinliği ve kubaşık öğrenme yöntemine ilişkin bir meta analiz çalışması. Yayınlanmamış doktora tezi, Çukurova üniversitesi, Adana.

[64] Taşkaya, S. M. ve Muşta, M. C. (2008). Sınıf öğretmenlerinin Türkçe öğretim yöntemlerine ilişkin görüşleri. Elektronik Sosyal Bilimler Dergisi, 7(25), 240-251.

[65] Topan, B. (2013). Matematik öğretiminde öğrenci merkezli yöntemlerin akademik başarı ve derse yönelik tutum üzerindeki etkililiği: Bir meta analiz çalışması. Yayınlanmamış yüksek lisans tezi, Kocaeli üniversitesi, Kocaeli.
[66] *Türkel, A. (2011). Yaratıcı dramanın yaratıcı yazma başarısına ve yazmaya karşı tutuma etkisi (İlköğretim 8. sınıf). Yayınlanmamış doktora tezi, Dokuz Eylül üniversitesi, İzmir.

[67] Ulubey, Ö. ve Toraman, Ç. (2015). Yaratıcı drama yönteminin akademik başarıya etkisi: Bir meta- analiz çalışması. Mustafa Kemal Üniversitesi Sosyal Bilimler Enstitüsü Dergisi, 12(32), 195-220.

[68] *Uysal, M. E. (2009). İlköğretim Türkçe dersinde işbirlikli öğrenmenin erişi, eleştirel düşünce ve yaratıcılık becerilerine etkisi. Yayınlanmamış doktora tezi, Dokuz Eylül üniversitesi, İzmir.

[69] Vural, B. (2004). Öğrenci Merkezli Eğitim ve Çoklu Zeka. İstanbul: Hayat Yayıncılik.

[70] *Yağmur Şahin, E. (2013). Materyal destekli eğitsel oyunların sokakta çalıştırılan çocukların Türkçe dil bilgisi başarı ve tutumlarına etkisi. Uluslararası Sosyal Araştırmalar Dergisi, 6(28), 459-468.

[71] Yalçın, A. (2006). Türkçe Öğretim Yöntemleri- Yeni Yaklaşımlar. Ankara: Akçağ Yayınları.

[72] *Yeşilyurt, E. (2011). 6. sınıflarda yapım eklerinin öğretimine yaratıcı drama yönteminin etkisi. Yayınlanmamış yüksek lisans tezi, Abant İzzet Baysal üniversitesi, Bolu.

[73] *Yönez, H. (2012). İs birlikli öğrenme yönteminin ilköğretim 8. sınıf Türkçe dersinde öğrencilerin derse ilişkin tutumlarına ve temel dil becerilerine etkisi. Yayınlanmamış yüksek lisans tezi, Gazi Üniversitesi, Ankara 